\title{
INTEGRASI NILAI-NILAI BUDAYA BIMA DALAM BAHAN AJAR PENDIDIKAN ISLAM
}

\author{
Abdul Munir \\ Fakultas Tarbiyah Institut Agama Islam Muhammadiyah Bima \\ moneragilbert928@gmail.com
}

\begin{abstract}
Abstrak
Tujuan penelitian ini adalah untuk mengetahui integrasi nilai-nilai budaya Bima ke dalam Bahan Ajar Pendidikan Islam. Penelitian ini merupakan penelitian dan pengembangan tahap implementasi dengan tahapan yaitu revisi bahan ajar dan produk akhir bahan ajar pendidikan Islam. Hasil penelitian menunjukkan bahwa terdapat beberapa langkah dalam melakukan integrasi nilai-nilai budaya Bima ke dalam Bahan ajar Pendidikan Islam yaitu: 1) pengidentifikasi, 2) Pengategorian, 3) Penyelarasan. Materi pendidikan Islam yang diintegrasikan dengan nilai-nilai budaya Bima meliputi: 1) Kejujuran dengan Nggahi rawi Pahu; 2) Takut dan Malu dengan Maja Labo Dahu; 3) Lingkungan dengan Ngaha Aina Ngoho; 4) Sosial dengan Ka Tupa Taho sama tewe sama Lemba; 5) Amanah dengan Suu sa wau tundu sa wale; 6) Kepemimpinan dengan Edesi ndai sura dou labo dana.
\end{abstract}

Kata Kunci: Bahan Ajar, Pendidikan Islam, Nilai-nilai budaya Bima.

\section{Pendahuluan}

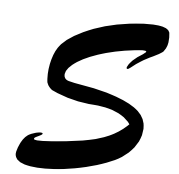

ejak awal tahun 2010, tepatnya pada tanggal 14 Januari 2010, pemerintah mencanangkan program "Pendidikan Budaya dan Karakter Bangsa" sebagai gerakan nasional. Pembangunan karakter yang merupakan upaya perwujudan amanat Pancasila dan Pembukaan UUD 1945 dilatarbelakangi oleh beragamnya permasalahan kebangsaan yang berkembang saat ini, seperti: disorientasi dan belum dihayatinya nilai-nilai Pancasila; keterbatasan perangkat kebijakan terpadu dalam mewujudkan nilai-nilai Pancasila; bergesernya nilai etika dalam kehidupan berbangsa dan bernegara; memudarnya kesadaran terhadap nilai-nilai budaya bangsa; ancaman disintegrasi bangsa; dan melemahnya kemandirian bangsa. ${ }^{1}$

Permasalahan dekadensi moral di atas terjadi juga pada kalangan remaja khususnya pelajar di Kabupaten Bima sebagai bagian generasi muda Indonesia. Perilaku menabrak etika, moral dan hukum dari yang ringan sampai yang berat masih kerap diperlihatkan oleh pelajar. Kebiasaan 'menyontek' pada saat ulangan atau ujian masih dilakukan. Hal lain yang menggejala adalah berbentuk kenakalan remaja berupa tawuran antarpelajar, pergaulan bebas, penyalahgunaan narkoba, pemalakan, bahkan penganiayaan. Semua perilaku negatif di kalangan pelajar tersebut di atas, jelas menunjukkan kerapuhan karakter yang cukup parah yang salah satunya disebabkan oleh tidak optimalnya pengembangan karakter di lembaga pendidikan di samping karena kondisi lingkungan yang tidak mendukung. ${ }^{2}$

${ }^{1}$ Pemerintah Republik Indonesia, Buku Induk Kebijakan Nasional Pembangunan Karakter Bangsa, (Jakarta; 2010), 2.

${ }^{2}$ Kemdiknas, Desain Induk Pendidikan Karakter, (Jakarta; 2010), 3. 
Uraian di atas menunjukkan bahwa terdapat dua hal yang menjadi penentu dalam proses pembentukan karakter bagi remaja, yaitu terfokus pada lembaga pendidikan dan lingkungan di luar lembaga pendidikan. Pembentukan karakter masyarakat Bima perlu digiatkan melalui pendidikan Islam dalam masyarakat mengingat bahwa masyarakat Bima sebagian besar adalah pemeluk Agama Islam. Selain itu saat ini kegiatan keagamaan dalam masyarakat Bima hanya sebatas pada kegiatan bacaan al-Qur'an melalui Taman Bacaan alQur'an (TBQ) tanpa melalui pendidikan agama dalam masyarakat secara sistematis.

Optimalisasi pendidikan Islam di masyarakat perlu dilakukan melalui pengintegrasian nilai-nilai luhur dalam masyarakat yang merupakan karakteristik khas dari masyarakat tersebut. Dalam konteks pendidikan di daerah Bima, maka perlu diupayakan bentuk pendidikan Islam berbasis budaya Bima, dalam hal ini nilai-nilai luhur daerah Bima. Pengintegrasian pola pelaksanaan pendidikan Islam secara nonformal di masyarakat dengan muatan nilai-nilai luhur daerah dipandang sebagai jembatan penghubung pendidikan sekolah dan pendidikan kemasyarakatan, di samping dalam rangka pelestarian budaya luhur daerah sebagai bagian budaya nusantara.

Materi pendidikan yang akan diintegrasikan adalah ajaran Islam dalam al-Qur'an dan al-hadis dengan nilai-nilai luhur budaya Bima dalam bentuk bahan ajar. Hal ini dimaksudkan untuk mempermudah penguatan dimensi agama dan budaya Bima yang sudah dikenal. Diharapkan menjadi "embrio" rutinitas kegiatan keagamaan yang terorganisir dan sistematis untuk mengatasi kevakuman penyelenggaraan pendidikan agama pada masyarakat Bima.

Atas dasar uraian di atas, permasalahan yang dirumuskan dalam tulisan ini, yaitu bagaimana integrasi nilai-nilai budaya Bima ke dalam bahan ajar pendidikan Islam.

\section{Dasar Pendidikan Islam Dan Nilai Budaya Bima}

Integrasi adalah pembauran hingga menjadi kesatuan yang utuh atau bulat. ${ }^{3}$ Sementara menintegrasikan adalah bermakna menggabungkan; menyatukan ${ }^{4}$.

Landecker membedakan tipe-tipe integrasi menjadi empat yaitu: Integrasi budaya atau konsisten diantara standar budaya, Integrasi normatif atau konsistensi antara standar budaya dan tingkah laku masyarakat, Integrasi komunikatif atau adanya jaringan komunikasi yang sesuai dengan sistem sosial, Integrasi fongsional atau tingkatan yang di sana ada hubungan kebebasab antara unit-unit dari sistem pembagian tenaga kerja. ${ }^{5}$ Integrasi memiliki makna dibangunnya interdepensi yang selaras antara nilai-nilai dalam beberapa aspek, sehingga integrasi ini adalah proses mempersatukan nilai-nilai yang menjadikan suatu aspek yang harmonis berdasarkan pada tatanan objek atau masyarakat setempat.

${ }^{3}$ Departemen Pendidikan Nasional, Kamus Besar Bahasa Indonesia, Edisi Ketiga (Jakarta: Balai Pustaka, 2007), 221.

${ }^{4}$ Departemen Pendidikan Nasional, Kamus Besar Bahasa Indonesia, 221.

${ }^{5}$ David L. Silis (ed), Internasional Encyclopedia of the Social Sciences, Vol. 7 (New York: The Macmillan Company \& The Press, 1986), 381. 
Saifuddin Sabba mengemukanan bahwa pengintegrasian beberapa aspek dalam pendidikan formal maupun non formal dapat dilakukan dengan tiga cara: pertama, melalui pencarian dasar dan padanan konsep, teori pengetahuan yang dicari dari Al-Qur'an dan hadis. Kedua, dengan cara mengambil atau mempelajari konsep dan teori aspek tersebut kemudian dipadukan dengan konsep dan teori aspek lainnya. Ketiga, dengan cara menemukan dan membangun aspek baru yang lebih baik. ${ }^{6}$

Dasar pendidikan Islam identik dengan dasar tujuan Islam. Keduanya berasal dari alQur'an dan hadis. Apa yang terkandung dalam pendidikan Islam itu dilandasi oleh al-Qur'an dan hadis. Kedua dasar tersebut dijelaskan sebagai berikut:

\section{Al-Qur'an}

Al-Qur'an merupakan kalam Allah swt. yang diturunkan kepada Nabi Muhammad saw. melalui malaikat Jibril. Di dalamnya terkandung tuntunan dasar yang dapat dikembangkan untuk kepentingan seluruh aspek kehidupan melalui ijtihad. Isi pokok yang terkandung dalam al-Qur'an terdiri dari tiga prinsip besar, yaitu berkaitan dengan masalah keimanan yang disebut akidah dan yang berhubungan dengan amal yang disebut syariah, serta yang berhubungan dengan tingkah laku yang dinamakan dengan akhlak.

Al-Qur'an terdapat banyak doktrin yang berisi prinsip-prinsip berkaitan dengan usaha pendidikan. Salah satu contoh dapat dilihat pada QS Lukman/:12-19, yang menceritakan cerita Lukman dalam mengajari anaknya. Di dalamnya dijelaskan bagaimana menetapkan prinsip materi pendidikan yang meliputi masalah iman, akhlak, ibadah, sosial dan ilmu pengetahuan. Di dalam ayat ini menceritakan tentang tujuan hidup dan nilai sesuatu kegiatan dan amal saleh. Dengan demikian bahwa pendidikan Islam harus menggunakan al-Qur'an sumber utama dalam merumuskan berbagai teori tentang pendidikan Islam. Sehingga boleh dikata bahwa pendidikan Islam harus berpatokan pada ayat-ayat al-Qur'an yang maksudnya dapat dikerjakan berdasarkan ijtihad serta diperbaharui sesuai dengan perubahan dan pembaharuan.

Al-Qur'an juga memuat nilai normatif yang menjadi acuan dalam pendidikan Islam. Nilai yang dimaksud terdiri atas tiga prinsip utama yaitu:

a. Khuluqiyyah, yang berhubungan dengan pendidikan etika, bertujuan untuk memurnikan diri dari tingkah laku rendah dan menghiasi jiwa dan raga dengan perilaku terpuji.

b. I'tiqadiyyah, berhubungan dengan pendidikan keimanan, seperti percaya kepada Allah, malaikat, rasul, kitab, hari kiamat dan takdir dengan maksud untuk memperbaiki dan memantapkan kepercayaan individu.

\footnotetext{
${ }^{6}$ Syaifuddin Sabda, Model Kurikulum Terpadu Iptek \& Imtaq, (Ciputat: Ciputat Press Group,2006), 47.
} 
c. Amaliyyah, adalah yang berkaitan dengan pendidikan cara berperilaku sehari-hari, baik hubungannya dengan pendidikan ibadah maupun pendidikan muamalah. ${ }^{7}$

Al-Qur'an membahas berbagai aspek kehidupan manusia, dan pendidikan merupakan tema terpenting yang dibahas. Setiap ayatnya merupakan bahan baku bangunan pendidikan yang dibutuhkan setiap manusia. Penjabarannya di dalam dunia pendidikan difokuskan kepada manusia dengan tidak keluar dari koridor Islam.

\section{Sunnah}

Al-Qur'an yang merupakan wahyu Allah swt. disampaikan oleh Rasullah saw. kepada umat manusia dengan penuh hikmah, tidak sedikitpun ditambah atau dikurangi. Setelah itu manusia hendak berusaha untuk memahaminya, menerimanya kemudian mengaplikasikannya. Ketika manusia menjumpai kesukaran dalam memahami alQur'an seperti yang dialami oleh para sahabat sebagai generasi pertama penerima alQur'an, maka mereka meminta pengarahan atau bimbingan kepada Rasulullah saw. yang memang diberi otoritas untuk itu.

Allah swt. melegitimasi Rasulullah saw. untuk menyampaikan wahyu tersebut sebagaimana firman-Nya dalam QS al-Nahl/16: 44.

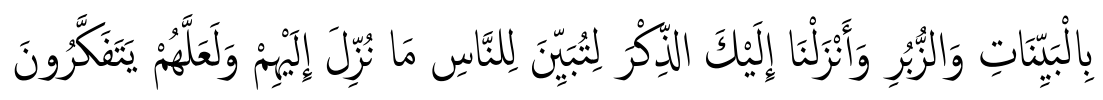

"(meraka Kami utus) dengan membawa keterangan-keterangan (mukzijat) dan kitab-kitab. Dan Kami turunkan al-Zikr (al-Qur'an) kepadamu, agar engkau menerangkan kepada manusia apa yang telah diturunkan kepada mereka dan agar mereka memikirkan". ${ }^{(\mathrm{QS}}$. Al-Nahl

Penjelasan itu di sebut al-Sunnah, yaitu segala perkataan, perbuatan, ataupun ketetapan Rasul, yang dicontohkan kepada sahabat dan umatnya melalui sifat, sikap dan akhlaknya untuk dijadikan teladan. Eksistensi kerasulan Muhammad saw. tersebut juga harus diakomodir oleh dunia pendidikan Islam. Pengajaran dan bimbingan yang diemban oleh dunia pendidikan selain harus bercermin kepada al-Qur'an juga memegang teguh teladan Rasulullah saw. ${ }^{9}$

Perintah yang mewajibkan kita mengikutinya, umumnya mencakup seluruh umat untuk seluruh masa dan tempat. Tidak ditentukan untuk zaman tertentu, tidak untuk sahabat dan tidak untuk masyarakat Arab saja. Hal ini berlaku pula untuk pendidikan Islam. Jika dunia pendidikan Islam mampu menyerap dan mengakomodir perintah dan larangan yang disampaikan Rasulullah maka akan jelas arah dan tujuan yang dicapai. Tetapi sebaliknya jika dunia pendidikan Islam mengambil jarak dari teladan Rasulullah

\footnotetext{
${ }^{7}$ Wahbah al-Zuhailiy, Ushul al-Fiqh Islami,(Damaskus: Dar al-Fikr, 1986), 438-439.

${ }^{8}$ Kementerian Agama RI, Al-Qur'an dan Terjemahnya, 272.

${ }^{9}$ Muhaimin dan Abdul Mujib, Pemikiran Pendidikan Islam, 39-40.
} 
maka proses dan hasil tujuan pendidikan itu akan terperosok ke dalam pemisahan antara agama dan pendidikan. Oleh karena itu, pendidikan Islam selalu menyelenggarakan pendidikan agama, yang lebih berfungsi sebagai sumber modal dan nilai. Sunnah menjabarkan semangat al-Qur'an yang tercermin dalam seluruh aspek kehidupan Nabi saw. adalah guru dan pendidik utama umat Islam.

Budaya Bima diyakini sebagai wasiat leluhur, biasa disebut "Nggahi ma Ntoi". ${ }^{10}$ Wasiat itu berupa pesan lisan yang diformulasikan dalam bahasa politis, kalimat berirama, ungkapan dan pantun/syair. Disampaikan pula secara lisan dari generasi ke generasi. Abdullah Tajib mengungkapkan bahwa "Nggahi ma Ntoi" dianggap sebagai konvensi mukaddimah dasar yang tidak tertulis untuk pegangan dalam mengatur mekanisme berkomunikasi antara penguasa dan rakyat dalam upaya bersama mencapai kesejahteraan hidup. ${ }^{11}$ Terdapat nilai-nilai luhur budaya Bima yang dikenal oleh masyarakat diantaranya berupa falsafah hidup: Maja Labo Dahu, Nggahi Rawi Pahu, Ngaha Aina Ngoho, dan Edesi Ndai Sura Dou Labo Dana. Selain itu terdapat nilai budaya Bima dalam aspek sosial keagamaan berupa budaya Sarimpu yang saat ini sudah memudar.

\section{Integrasi Nilai-nilai Budaya Bima dalam Bahan Ajar}

\section{Pendidikan Islam}

Nilai budaya merupakan konsep abstrak mengennai masalah besar dan bersifat umum yang sangat penting dan sangat bernilai bagi kehidupan bermasyarakat. Nilai itu menjadi acuan tingkah laku bagi mayoritas anggota masyarakat, berada dalam alam pikiran mereka dan sulit diterangkan secara rasional. Pada masyarakat Bima, nilai-nilai budaya sudah mengakar menjadi falsafah hidup yang bersifat langgeng, tidak mudah berubah ataupun tergantikan oleh nilai budaya lain. Masyarakat Bima memiliki nilai sebagai hasil proses pembelajaran sejak masa kanak-kanak hingga dewasa yang telah mendarah dading.

Pengintegrasian nilai-nilai budaya Bima dalam bahan ajar pendidikan Islam dilakukan dengan beberapa langkah. Langkah pertama adalah mengidentifikasi nilai-nilai. Dalam melakukan pengintegrasian nilai-nilai budaya Bima dengan Pendidikan Islam, diawali dengan mencari nilai-nilai budaya Bima selanjutnya dikumpulkan untuk dipahami makna yang terkandung padanya melalui literatur-literatur dan tokoh budaya yang berkompeten di bidangnya. Kedua mengategorikan nilai-nilai budaya Bima. Setelah terkumpul dan memahami makna masing-masing, selanjutnya dilakukan pengategorian nilai tersebut untuk diintegrasikan ke dalam pendidikan Islam. Ketiga adalah menyelaraskan nilai-nilai budaya

\footnotetext{
${ }^{10}$ Siti Maryam. Revitalisasi Budaya Bima Ditengah Transformasi Sosial. Bunga Rampai Pengembangan Daerah Bima, (Yogyakarta: Aditya Media, 1999), 19-24.

11 Abdullah Tajib. Revitalisasi Budaya Bima Ditengah Transformasi Sosial. Bunga Rampai Pengembangan Daerah Bima (Yogyakarta: Aditya Media,1999), 25-30.
} 
Bima yaitu penyesuaian/penyelarasan nilai-nilai luhur budaya Bima yang dipadukan materi pendidikan Islam hingga mencapai suatu keserasian fungsi di dalam kehidupan masyarakat.

Materi pendidikan Islam yang telah diintegrasikan dengan nilai-nilai budaya Bima meliputi: 1) Kejujuran dengan Nggahi rawi Pahu; 2) Takut dan Malu dengan Maja Labo Dahu; 3) Lingkungan dengan Ngaha Aina Ngoho; 4) Sosial dengan Ka Tupa Taho sama tewe sama Lemba; 5) Amanah dengan Suи sa wau tundu sa wale; 6) Kepemimpinan dengan Edesi ndai sura dou labo dana.

\section{Nggahi rawi pahu dengan Kejujuran}

Nilai budaya Bima Nggahi rawi pahu mencerminkan kesesuain antara ucapan dengan perbuatan. Nggahi berarti perkataan, rawi berarti perbuatan, dan pahu berarti sesuai atau rupa. Hal ini sangat selaras dengan konsep jujur dalan Islam. Ayat al-Qur'an yang sesuai dengan konsep Nggahi rawi pahu dapat ditemukan pada QS. al-Shaf ayat 2-3.

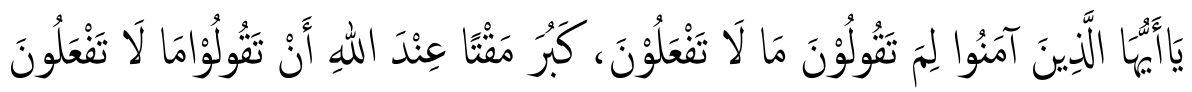

Wahai orang-orang yang beriman, kenapakah kamu mengatakan sesuatu yang tidak kamu kerjakan? Amat besar kebencian di sisi Allah bahwa kamu mengatakan apa-apa yang tidak kamu kerjakan. ${ }^{12}$ (QS. Al-Shaf[61]: 2-3)

Nilai Nggahi Rawi Pahu, menuntut adanya kejujuran hati dan lisan dalam konteks personal atau pribadi dan juga merefleksikan karakter kejujuran dalam konteks yang lebih luas, yaitu umat.

Hadis Rasulullah:

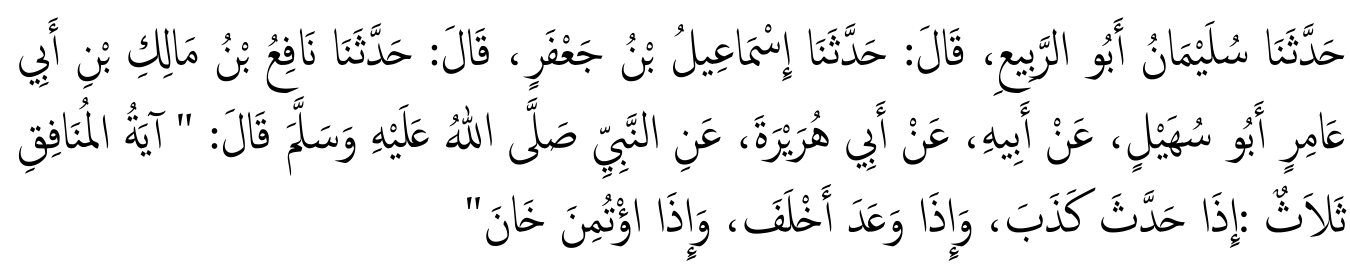

'Sulaiman abu Rabi' berkata Ismail bin Ja'far berkata Naïf bin Malik bin abu 'Amir abu Suhail dari Malik abi Amir dari abu Hurairah, Rasulullah saw. bersabda:"Tanda-tanda orang munafik ada tiga macam yaitu : apabila ia berbicara berdusta, apa bila berjanji ingkar dan apabila dipercaya khianat." (HR. Bukhari dan Muslim)

\section{Maja labo dahu dengan Malu dan takut}

Nilai budaya Bima Maja labo Dahu memiliki dua aspek yaitu maja berarti budaya malu dan $d a h u$ berarti budaya takut.

\footnotetext{
${ }^{12}$ Kementerian Agama RI, Al-Qur'an dan Terjemahnya, 440.
} 
Nilai budaya malu yang tertanam dalam jiwa setiap insan menjadikan seseorang mampu mengendalikan diri untuk tidak berbuat sesuatu yang tidak baik (terlarang), yang dipandang tidak patut dan tidak sesuai dengan etika kehidupan manusia yang bermoral dan beradab. Rasa malu yang terpancar dari dalam jiwa seseorang akan mengendalikan nafsunya sehingga tidak melanggar norma agama, norma adat, norma susila dan norma hukum.

Hadis Rasulullah:

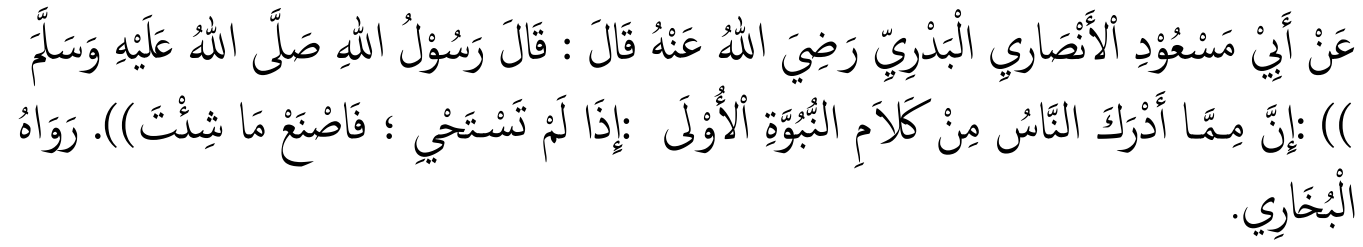

"Dari Abu Mas'ud 'Uqbah bin 'Amr al-Anshari al-Badri radhiyallahu 'anhu ia berkata, "Rasulullah Shallallahu 'alaihi wa sallam bersabda, 'Sesungguhnya salah satu perkara yang telah diketahui oleh manusia dari kalimat kenabian terdahulu adalah, 'Jika engkau tidak malu, berbuatlah sesukamu." (Hadis Riwayat Bukhary no. 3483)

Sedangkan aspek Dahu mengandung pengertian takut yaitu takut kepada Allah swt. maka dalam ajaran Islam inilah yang disebut dengan Taqwa.

Malu dan takut saling melengkapi sehingga ajaran atau budaya tersebut mampu membentuk kepribadian yang di dalamnya tertanam nilai moral yang luhur sebagai wahana pengendalian diri yang ampuh. Ayat al-Qur'an yang terkait dengan konsep dahu atau takut terdapat pada beberapa ayat, diantaranya pada surat al-Nur ayat 52:

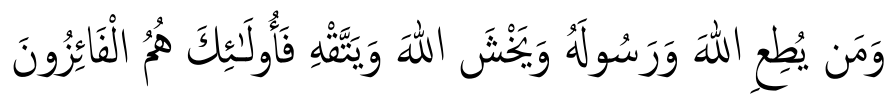

"Dan barang siapa yang taat kepada Allah dan rasul-Nya dan takut kepada Allah dan bertakwa kepada-Nya, Maka mereka adalah orang- orang yang mendapat kemenangan". ${ }^{13}$ (QS. Al-Nur[24]:52)

Takut kepada Allah ialah takut disebabkan dosa-dosa yang telah dikerjakannya, dan yang dimaksud dengan taqwa ialah memelihara diri dari segala macam dosa-dosa yang mungkin terjadi.

\section{Suu Sa Wau Tundu Sa Wale dengan Amanah}

Nilai budaya Bima Suи Sa Wau Tundu Sa Wale mencerminkan sifat dan sikap yang mulia, di antaranya yaitu: Pertama sifat amanah. Sebesar apapun tugas kewajiban diembankan maka harus dijunjung dan dipikul atau dilaksanan. Kedua, sikap kesatria

\footnotetext{
${ }^{13}$ Kementerian Agama RI, Al-Qur'an dan Terjemahnya, 284.
} 
sebagai ciri, watak, dan semangat kerja keras orang Bima. Hal ini sangat sejalan dengan konsep ibadah yang tidak boleh melalaikan amanah serta perintah untuk kerja keras.

Ayat al-Qur'an terkait amanah terdapat pada QS. al-Nisa' ayat 58.

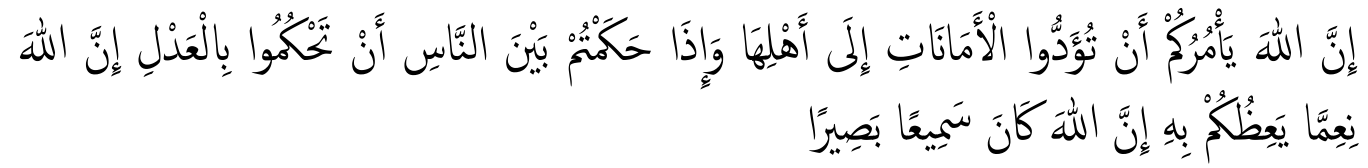

"Sesungguhnya Allah menyuruh kamu menyampaikan amanat kepada yang berhak menerimanya, dan (menyuruh kamu) apabila menetapkan hukum di antara manusia supaya kamu menetapkan dengan adil. Sesungguhnya Allah memberi pengajaran yang sebaik-baiknya kepadamu. Sesungguhnya Allah adalah Maha mendengar lagi Maha melihat". ${ }^{14}$ (QS. Al-Nisa' [3]:58)

Hadis Rasulullah :

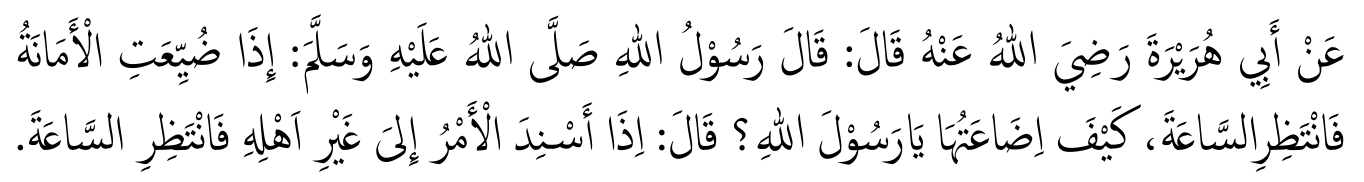

"Apabila sudah hilang amanah maka tunggulah terjadinya kiamat, seorang bertanya: Bagaimana hilangnya amanah itu? Rasulullah bersabda: Jika urusan diserahkan bukan kepada ahlinya, maka tunggulah terjadinya kiamat". ${ }^{15}$

\section{Ngaha aina Ngoho dengan Lingkungan (alam)}

Nilai Ngaha Aina Ngoho menuntut dan ajakan agar masyarakat berhemat dalam ekonomi dan memanfaatkan sumber daya alam seperti air, hutan, dan lingkungan demi hari esok dan anak cucu. Ngaha berarti makan atau manfaatkan, aina yang berarti Jangan atau larangan, ngoho berarti pembabatan hutan atau boros. Lingkungan jangan dirusak karena keserakahan, masyarakat harus memperhatikan untuk masa depan dan anak cucu. Nilai ngaha aina ngoho ini selaras dengan perintah Allah sebagaimana yang tercantum pada QS. al-Rum ayat 41.

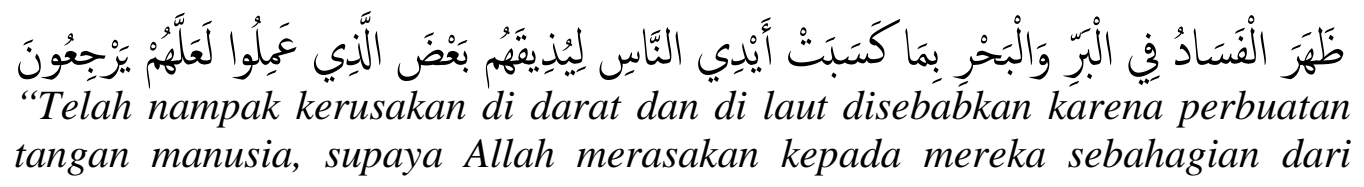

\footnotetext{
${ }^{14}$ Kementerian Agama RI, Al-Qur'an dan Terjemahnya, 69.

${ }^{15}$ Imam Bukhari, Kitab al Ahkam, Bab Qauli Allah Ta'ala (Athi'u Allaha wa Athi'u ar Rasula wa Uli al Amri Minkum), 34. Lihat dan bandingkan H.E, Hassan Saleh, Kajian Fiqh Nabawi dan Fiqh Kontemporere, (Jakarta: Rajawali Pers, 2008), 473.
} 
(akibat) perbuatan mereka, agar mereka kembali (ke jalan yang benar) ". ${ }^{16}$ (QS. Al-Rum[30]:41)

Selain untuk beribadah kepada Allah, manusia juga diciptakan sebagai khalifah di muka bumi. Sebagai khalifah, manusia memiliki tugas untuk memanfaatkan, mengelola dan memelihara alam semesta. Allah telah menciptakan alam semesta untuk kepentingan dan kesejahteraan semua makhluk-Nya, khususnya manusia. Keserakahan dan perlakuan buruk sebagian manusia terhadap alam dapat menyengsarakan manusia itu sendiri. Sebagaimana Firman Allah dalam surat al-A'raf ayat 56-58.

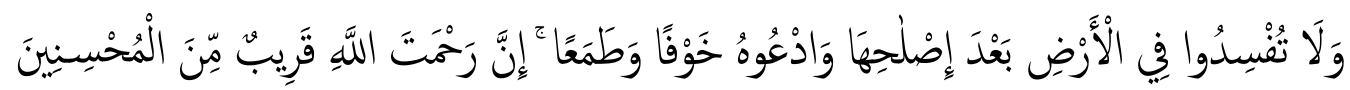

"Dan janganlah kamu berbuat kerusakan di muka bumi sesudah (Allah) memperbaikinya dan berdoalah kepadanya rasa takut (tidak akan diterima) dan harapan (akan dikabulkan). Sesungguhnya rahmat Allah amat dekat kepada orang-orang yang berbuat baik". ${ }^{17}$ (Al-A'raf[7]: 56-58)

Bumi sebagai tempat tinggal dan tempat hidup manusia dan makhluk Allah lainnya sudah dijadikan Allah dengan penuh rahmat-Nya. Gunung-gunung, lembahlembah, sungai-sungai, lautan, daratan dan lain-lain semua itu diciptakan Allah untuk diolah dan dimanfaatkan dengan sebaik-baiknya oleh manusia, bukan sebaliknya dirusak dan dibinasakan.

\section{Edesi Ndai Sura Dou Labo Dana dengan Kepemimpinan}

Nilai Edisi Ndai sura Dou Labo Dana memberikan penekanan bahwa seorang pemimpin/raja/pemerintah/penguasa seharusnya memiliki sikap kepemimpinan yaitu mendahulukan kepentingan rakyat dan negara dari pada kepentingan pribadi dan golongan. Sikap kepemimpinan ini telah diajarkan oleh Islam melalui Rasulullah saw. Bagaimana etika dan akhlak seoarang pemimpin. Hal ini telah diinformasikan dalam hadisnya.

Hadis Rasulullah:

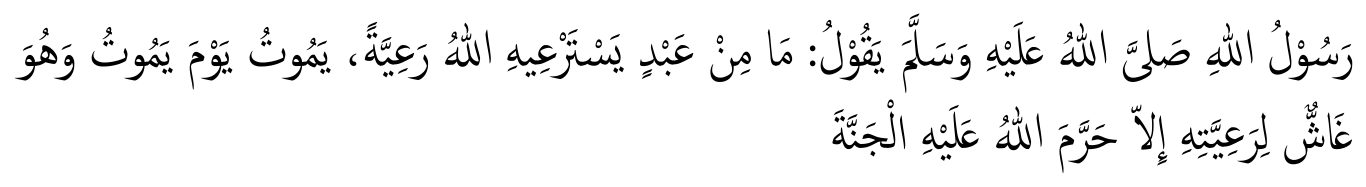

\footnotetext{
${ }^{16}$ Kementerian Agama RI, Al-Qur'an dan Terjemahnya, 326.
}

${ }^{17}$ Kementerian Agama RI, Al-Qur'an dan Terjemahnya, 125. 
"Tiada seorang yang diamanati oleh Allah memimpin rakyat, kemudian ketika ia mati ia masih menipu rakyatnya, melainkan pasti Allah mengharamkan baginya surga". ${ }^{18}$

Seorang pemimpin, selayaknya harus meniru tindak tanduk dari apa yang sudah diajarakan oleh Rasulullah saw., terutama dalam akhlak atau moralitas kepemimpinan. Hal tersebut sebagaimana disebutkan dalam QS al-Taubah ayat 128.

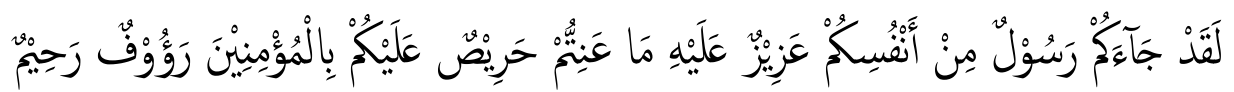

"Sungguh Telah datang kepadamu seorang Rasul dari kaummu sendiri, berat terasa olehnya penderitaanmu, sangat menginginkan (keimanan dan keselamatan) bagimu, amat belas kasihan lagi Penyayang terhadap orang-orang mukmin". ${ }^{19}$ (QS. At-Taubah[9]: 128)

Berdasarkan ayat di atas, ada 3 sikap moral kepemimpinan Rasulullah saw. yang perlu dicermati dan diteladani oleh setiap pemimpin. Pertama, 'azizun alaihi ma 'anittum (artinya, amat berat dirasakan oleh Nabi apa yang menjadi beban penderitaan umat yang dipimpinnya). Dalam istilah modern, sikap ini disebut "sense of crisis", yaitu rasa peka atas kesulitan rakyat yang ditunjukkan dengan kemampuan berempati dan simpati kepada pihak-pihak yang kurang beruntung. Seorang pemimpin ia harus berada digarda terdepan ketika ada rakyatnya di dzolimi. Selalu hadir ketika ada rakyatnya diperlakukan tidak adil. Tidak hanya sekedar prihatin saja, tetapi harus beraksi. Karena, banyak kasus di tengah kita yang akhirnya mangkrak kasusnya, karena pemimpinnya tidak membela yang benar, tetapi membela yang bayar.

Kedua, harishun `alaikum (artinya, Nabi sangat mendambakan agar umat yang dipimpinnya aman dan sentosa). Dalam istilah modern, sikap ini disebut sense of achievement, (bacanya: Sens of acivfment) yaitu semangat dan perjuangan yang sungguh-sungguh, agar seluruh masyarakat yang dipimpinannya dapat meraih kemajuan dan kemakmuran. Bangsa Indonesia dikenal bangsa kaya raya dan gemah lipah loh jinawi, tetapi yang menikmati kekayaan itu adalah bangsa asing. Hasil minyak bumi, air, batu bara di ekspor habis-habisan ke luar negeri, sehingga menjadikan rakyat ini susah, harga bahan bakar minyak (BBM) melejit. Semuanya serba mahal. Sebab itu, ini adalah pekerjaan rumah (PR) besar pemimpin mendatang.

Ketiga, raufun rahim (artinya, sikap mengasihi dan menyayangi). Allah swt. adalah Tuhan Yang Maha Pengasih lagi Maha Penyayang. Demikian pula Rasulullah saw., juga merupakan manusia yang sangat pengasih dan penyayang. Maka sudah seharusnya bagi setiap mukmin, terutama mereka yang dipercaya menjadi pemimpin,

${ }^{18}$ Imam al-Bukhari dalam kitab al-Ahkam juz 4 hal 235 dan diriwayatkan oleh imam Muslim dalam kitab al-Iman juz 1 hal 88 (dikutip dari catatan kaki kitab Bulugh al-Maram Min Adillah al-Ahkam hal 606 hadits no. 1517)

${ }^{19}$ Kementerian Agama RI, Al-Qur'an dan Terjemahnya, 165. 
meneruskan kasih sayang Allah dan Rasul-Nya itu dengan cara mencintai dan mengasihi orang lain, khususnya masyarakat yang dipimpinnya. Karena kasih sayang (rahmat) adalah pangkal dari segala kebaikan. Tanpa kasih sayang, sangat sulit dibayangkan seseorang bisa berbuat baik.

Dengan demikian, jika para pemimpin-pemimpin kita meneladani akhlak kepemimpinan Rasulullah saw., insya Allah Negara kita akan makmur sentosa. Tidak ada korupsi. Tidak ada penyalahgunaan jabatan, hukum dan keadilan ditegakkan dengan baik.

\section{Ka Tupa Taho, Sama Tewe Sama Lemba dengan Sosial (gotong royong)}

Nilai Ka Tupu Taho Sama Tewe sama Lemba mengajarkan agar dalam membangun hendaknya dilakukan secara gotong royong, ringan sama dijinjing berat sama dipikul. Nilai ini membentuk karakter orang Bima yang dikenal rukun dan cinta kebersamaan dan memupuk rasa kesetiakawanan sosial. Sehingga nilai Ka Tapu Taho Sama Tewe sama Lemba ini sangat selaras dengan pendidikan Islam yang mementingkan kebersamaan atau saling bantu dalam kebaikan. Sebagaimana telah tercantum dalam QS. al-Maidah ayat 2.

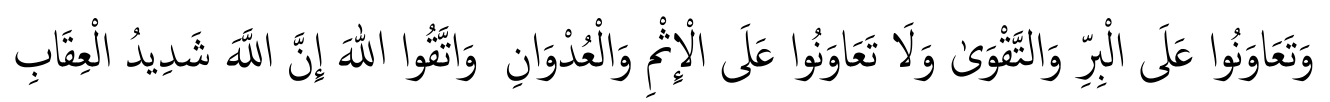

"Dan tolong-menolonglah kamu dalam (mengerjakan) kebajikan dan takwa, dan jangan tolong-menolong dalam berbuat dosa dan pelanggaran. dan bertakwalah kamu kepada Allah, sesungguhnya Allah amat berat siksa-Nya”. ${ }^{20}$ (QS. AlMaidah[5]: 2)

Islam telah memerintah kepada orang-orang Islam agar menjalin silaturahmi sebagaimana disebutkan pada QS. al-Nisa' ayat 1.

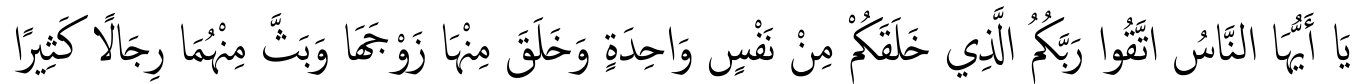

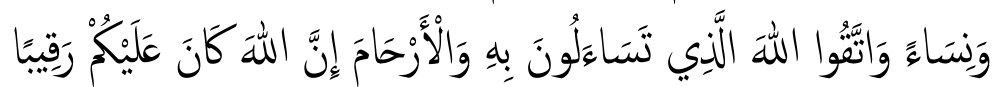

"Hai sekalian manusia, bertakwalah kepada Tuhan-mu yang Telah menciptakan kamu dari seorang diri, dan dari padanya Allah menciptakan isterinya; dan dari pada keduanya Allah memperkembang biakkan laki-laki dan perempuan yang banyak. dan bertakwalah kepada Allah yang dengan (mempergunakan) namaNya kamu saling meminta satu sama lain, dan (peliharalah) hubungan silaturrahim. Sesungguhnya Allah selalu menjaga dan mengawasi kamu. ${ }^{21}$ (QS. al-Nisa: 1)

\footnotetext{
${ }^{20}$ Kementerian Agama RI, Al-Qur'an dan Terjemahnya, 85.

${ }^{21}$ Kementerian Agama RI, Al-Qur'an dan Terjemahnya, 61.
} 
Silaturahmi, kata wal-arham dalam ayat ini menujukan perintah untuk melaksanakan silaturahmi kepada sesama manusia karena dengan silaturahmi manusia bisa menjalin hubungan sosial dengan baik.

Dengan silaturahmi baik kepada keluarga maupun kepada orang-orang sekitar kita, tentangga, lingkungan sekolah, lingkungan belajar, dan lain-lain, kita harus senantiasa membangun kerja sama, saling membantu, gotong royong. Bekerja sama menjadikan pekerjaan yang berat menjadi ringan, tetapi harus dalam hal-hal yang baik saja. Bekerjasama tidak boleh dilakukan dalam hal-hal yang buruk seperti, kerja sama untuk mencuri, berbuat maksiat, bohong, tidak jujur, mengganggu teman, dan lain-lain.

\section{Penutup}

Berdasarkan uraian pada hasil penelitian di atas bahwa terdapat beberapa langkah dalam melakukan integrasi nilai-nilai budaya Bima ke dalam Bahan ajar Pendidikan Islam yaitu: 1) pengidentifikasi, 2) Pengategorian, 3) Penyelarasan. Materi pendidikan Islam yang diintegrasikan dengan nilai-nilai budaya Bima meliputi: 1) Kejujuran dengan Nggahi rawi Pahu; 2) Takut dan Malu dengan Maja Labo Dahu; 3) Lingkungan dengan Ngaha Aina Ngoho; 4) Sosial dengan Ka Tupa Taho sama tewe sama Lemba; 5) Amanah dengan Suu sa wau tundu sa wale; 6) Kepemimpinan dengan Edesi ndai sura dou labo dana.

\section{Daftar Pustaka}

David L. Silis (ed), Internasional Encyclopedia of the Social Sciences, Vol. 7 New York: The Macmillan Company \& The Press, 1986.

Departemen Pendidikan Nasional, Kamus Besar Bahasa Indonesia, Edisi Ketiga Jakarta: Balai Pustaka, 2007.

Kemdiknas, Desain Induk Pendidikan Karakter, Jakarta; 2010.

Kementerian Agama RI., al-Quran dan Terjemahan, Bekasi: Darul Haq, 2014.

Mujib, Abdul., Muhaimin, Pemikiran Pendidikan Islam, Bandung: Trigenda Karya, 2007.

Pemerintah Republik Indonesia, Buku Induk Kebijakan Nasional Pembangunan Karakter Bangsa, Jakarta; 2010.

Sabda, Syaifuddin, Model Kurikulum Terpadu Iptek \& Imtaq, Ciputat: Ciputat Press Group,2006.

Tajib, Abdullah. Revitalisasi Budaya Bima Ditengah Transformasi Sosial. Bunga Rampai Pengembangan Daerah Bima. Yogyakarta: Aditya Media,1999.

W.R. Borg and M.D. Gall, Education Research: an Introduction. London: Longman, inc., 1983.

Wahbah al-Zuhailiy, Ushul al-Fiqh Islami. Damaskus: Dar al-Fikr, 1986. 